\title{
Geochemical Precursors to Seismic Activity
}

\author{
DONALD THOMAS ${ }^{1}$
}

\begin{abstract}
Studies of earthquake precursory phenomena during the last several decades have found that significant geophysical and geochemical changes can occur prior to intermediate and large earthquakes. Among the more intensely investigated geochemical phenomena have been: (1) changes in the concentrations of dissolved ions and gases in groundwaters and (2) variations in the concentrations of crustal and mantle volatiles in ground gases. The concentration changes have typically showed no consistent trend (either increasing or decreasing), and the spatial and temporal distribution of the observed anomalies have been highly variable. As a result, there is little agreement on the physical or chemical processes responsible for the observed anomalies. Mechanisms proposed to account for precursory groundwater anomalies include ultrasonic vibration, pressure sensitive solubility, pore volume collapse, fracture induced increases in reactive surfaces, and aquifer breaching/fluid mixing. Precursory changes in soil gas composition have been suggested to result from pore volume collapse, micro-fracture induced exposure of fresh reactive silicate surfaces, and breaching of buried gas-rich horizons. An analysis of the available field and laboratory data suggests that the aquifer breaching/fluid mixing (AB/FM) model can best account for many of the reported changes in temperature, dissolved ion and dissolved gas concentrations in groundwater. Ultrasonic vibration and pressure sensitive solubility models cannot reasonably account for the geochemical variations observed and, although the pore collapse model could explain some of the observed chemical changes in groundwater and ground gas, uncertainties remain regarding its ability to generate anomalies of the magnitude observed. Other geochemical anomalies, in particular those associated with hydrogen and radon, seem best accounted for by increases in reactive surface areas (IRSA model) that may accompany precursory deformation around the epicenter of an impending earthquake. Analysis of the probable response of these models to the earthquake preparation process, as well as to other environmental factors, suggests that geochemical monitoring programs can provide information that may be valuable in forecasting the probability of an earthquake; however, because of the complexity of the earthquake preparation process, the absolute prediction of seismic events using geochemical methods alone, does not presently appear to be feasible.
\end{abstract}

Key words: Earthquake prediction, earthquake precursors.

\section{Introduction}

It is generally agreed that earthquakes can be preceded by several types of 'anomalous' geochemical phenomena. Beyond this, there is little agreement as to the significance, mechanism, or even the definition of an 'anomalous earthquake

\footnotetext{
${ }^{1}$ Hawaii Institute of Geophysics, University of Hawaii at Manoa, 2525 Correa Road, Honolulu,
} Hawaii 96822 
precursor.' This lack of agreement arises largely from the uniqueness of each set of precursors, which often consist of a diverse group of anomalies that appear in unpredictable locations and have few common characteristics that would allow a clear determination of their underlying physical or chemical mechanisms. As a result, the number of earthquakes successfully forecasted using precursory phenomena is most notable for its small size. Nonetheless, the frequency of restrospective reports of geochemical anomalies associated with subsequent seismic events suggests that geophysical phenomena associated with the earthquake preparation process can produce precursory changes in the compositions of groundwaters and ground gases. Before these precursors can be successfully used to forecast earthquakes, we must first understand the mechanisms that relate the earthquake preparation process to the geochemical changes that have so frequently been observed.

The present review summarizes recent research results from the application of geochemical methods to earthquake forecasting and focuses primarily on precursory changes observed in the concentrations of dissolved ions and gases in groundwater and of inert and reactive gases in the shallow soil environment. The observational database is presented first and includes a discussion of the geochemical monitoring methodology, observed earthquake precursors, and nonseismic interferences for the different techniques. Next is a discussion of the mechanisms proposed to account for the precursory anomalies and an analysis of each mechanism in terms of its ability to account for the anomalies and of supporting or conflicting laboratory data. Finally, an assessment is offered of the potential utility of several current monitoring protocols to earthquake forecasting.

\section{Geochemical Anomalies in Groundwaters}

Groundwater anomalies have been among the earliest and most frequently reported phenomena to occur in conjunction with earthquake activity. Historical accounts of precursors in Japan, summarized by WAKITA (1982), and more recent observations in China (JIANG and LI, 1981a) report changes in taste and temperature in wells and springs prior to many large earthquakes. More sophisticated monitoring of groundwater supplies has confirmed the earlier qualitative reports and has recorded substantial precursory changes in a variety of chemical species. Groundwater monitoring programs typically consist of discrete sampling of wells or springs at intervals of weeks to months and subsequent analysis of selected ions and gases. The most frequently monitored dissolved ions include group I and II cations (e.g., sodium, potassium, calcium, and magnesium), major anions (e.g., sulfate, chloride, fluoride, and carbonate) and, less often, trace element concentrations (mercury, radium, uranium, fluoride, lithium, strontium and barium) (BARSUKov et al., 1979a, 1979b, 1985; ChUNG, 1981; KING et al., 1981; CAI et al., 1984; LI et al., 1985). Dissolved gases investigated for precursory variations include $\mathrm{CO}_{2}, \mathrm{H}_{2} \mathrm{~S}, \mathrm{CH}_{4}, \mathrm{He}$, 
$\mathrm{Ne}, \mathrm{Ar}, \mathrm{N}_{2}, \mathrm{H}_{2}$, and $\mathrm{Rn}$. Deep wells, mineral springs and natural thermal springs are the preferred sampling sources, since they are less susceptible to influence from seasonal changes in recharge or to pumping of nearby wells, but some studies have also included shallow water sources, due to their ease of sampling and availability.

\section{Dissolved ion precursors}

Anomalies in the concentrations of a variety of dissolved ions present in groundwater have been widely observed. The anomalies are typically associated with earthquakes of magnitude 4 or larger and have been reported prior to intra-plate earthquakes in China and the Soviet Union (BARSUKov et al., 1979a, 1979b, 1985; JiANG and LI, 1981a; CAI et al., 1984; ZhU et al., 1984; Lr et al., 1985), subduction zone seismic events in Japan (WAKITA, 1977; 1981; 1982; 1984), and inter-plate strike slip earthquakes in the United States (CraIG et al., 1980; KING et al., 1981). The trends and shapes of the anomalies are quite variable within a given set of anomalies and between different anomalous periods; ion concentrations may increase or decrease, over a period of weeks or months, or appear as short 'spike-like' changes that last for a period of a few days or less. In a few cases, water sources showed permanent changes in the composition of a groundwater source or in their response to nearsurface recharge (CAI et al., 1984). Several studies have reported that the concentrations of a suite of ions were found to change concurrently (JIANG and LI, 1981a) and, in others, chemical anomalies in some wells were contemporaneous with changes in groundwater flow rates or temperatures in others (CAI et al., 1984; ZHU et al., 1984); in a few instances, chemical and hydrologic changes were reported for the same water sources (KING et al., 1981; CAI et al., 1984).

The amplitude and distribution of geochemical changes have been postulated by some researchers to provide an indication of the location and magnitude of impending seismic events (BARsukov et al., 1985; SARdov, 1981; ZHU et al., 1984), but most studies have been unable to confirm a pattern in the location of anomalies. More often, the anomalies seem to be almost randomly scattered around the epicenter, with some preferential distribution along fault systems (CAI et al., 1984; ZHU et al., 1984). Several studies have also reported minor precursory changes in water sources within the epicentral zone, but substantial changes in more distant wells (KING, 1985a; KING et al., 1981; Li et al., 1985).

\section{Dissolved gas precursors}

Changes in gas emissions from thermal and nonthermal wells and the discharge of odorous or flammable gases from the earth have been prominently reported in accounts of preseismic phenomena for well over 100 years (IRWIN and BARNES, 1980; WaKITA, 1982; ZIA, 1984; Gold and Soter, 1985; KING, 1986). Among the more spectacular phenomena reported are descriptions of gas jets from dry wells, sand 
geysers, and large increases of gas effervescing from springs (JIANG and LI, 1981a; LI et al., 1985). The primary component of these gases is often reported to be carbon dioxide, although methane and hydrogen sulfide are probable constituents of flammable or odorous discharges, respectively (CAI et al., 1984). More quantitative studies of gas discharges have recently monitored the concentrations of both reactive gases, such as $\mathrm{CO}_{2}, \mathrm{H}_{2} \mathrm{~S}, \mathrm{CH}_{4}, \mathrm{NH}_{4}$, and inert gases, $\mathrm{He}, \mathrm{Ne}, \mathrm{Ar}, \mathrm{Rn}, \mathrm{N}_{2}$, and $\mathrm{H}_{2}$.

Precursory anomalies of the more reactive gases are typically governed by the geology of the area being monitored. Methane and hydrogen sulfide anomalies are reported in areas of known coal or petroleum deposits or organic-rich shale horizons (SUGISAKI et al., 1980; KAWABE et al., 1981; CAI et al., 1984; BarSUKov et al., 1985; KAWABE, 1985) and carbon dioxide discharges have been observed in limestone formations or shallow alluvial deposits (CAI et al., 1984; LI et al., 1985). The trends of the gas concentration anomalies have been quite variable; several investigators (CAI et al., 1984; NerSESov, 1984; KAWABE, 1985) report increases in gas concentrations, but others report declines in concentrations or concentration ratios immediately prior to seismic events (KING et al., 1981; BARSUKOV et al., 1985; SugISAKI and SUGIURA, 1986).

Gas anomalies typically occur more frequently in the epicentral region of an impending earthquake, but have also been observed at distances of several hundred kilometers from the epicentral area (CAI et al., 1984; NerSESOv, 1984). Their broad distribution has been inferred to reflect the sensitivity of gas anomalies to regional changes in the stress field associated with the earthquake preparation process. The specific locations within the epicentral region that show precursors have been suggested to depend upon the proximity of the monitored water source to points of stress concentration (e.g., on fault traces or other 'sensitive areas'), the presence of chemically distinct aquifers, or upon whether the groundwaters are sampled from confined or unconfined aquifers. CAl et al., (1984) suggest that, as a result of these multiple influences, the intensity of observed anomalies are of little value in predicting the magnitude of the impending seismic event.

Most precursory monitoring investigations of nonreactive gases have studied variations in the absolute and relative concentrations of $\mathrm{He}, \mathrm{Ne}, \mathrm{Ar}, \mathrm{Rn}$, and $\mathrm{N}_{2}$, in an effort to identify anomalies and to differentiate between precursors and nonseismic interferences. A limited number of other investigations have also analyzed their isotopic compositions as a means of determining the source of the gases.

Helium has been analyzed as both a potential earthquake precursor as well as a possible tracer for hidden or buried fault systems in several different geologic provinces (BUlaSHEVICH and BASHORIN, 1973; DikUn et al., 1975; BUlASHEVICH et al., 1976; WAKITA, 1977, 1978, 1982; BARSUKov et al., 1979a, 1979b, 1982, 1985). These studies have reported helium enrichments in spring and well waters discharged from recently active faults, as well as precursory helium anomalies (CHALOv et al., 1977; BARSUKOV et al. 1979a, 1985; WAKITA, 1982). BARSUKOV et al. (1979a, 1985) have suggested that the shape and duration of groundwater helium anomalies could be 
used to estimate the distance and magnitude of an impending seismic event; other investigators have been unable to find such a correlation.

In order to overcome nonseismic interferences in the absolute concentrations of helium (and other inert gases) in groundwater (see Environmental Interferences following), several studies have also monitored gas concentration ratios. These studies have generally obtained contradictory results: SUGISAKI (1978) and SUGISAKI and Sugrura (1986) found that $\mathrm{He} / \mathrm{Ar}$ and $\mathrm{N}_{2} / \mathrm{Ar}$ ratios decreased substantially prior to some earthquakes, but similar studies (KAWABE et al., 1981; KAWABE, 1985) report only minor precursory variations in the rare gas ratios. These investigations indicate, however, that mixing of fluids having gases derived from atmospheric and crustal sources may be responsible for the observed variations in the concentration ratios (KAWABE et al., 1981; Li et al., 1985; SUGISAKI and SugIURA, 1986).

Other investigators have used isotopic analyses to characterize the source of helium found. Barsukov et al. (1985) found helium anomalies with low $\mathrm{He}^{3} / \mathrm{He}^{4}$ ratios, indicating that their source was radiogenic helium from crustal rocks. WAKITA (1978) and SANo et al. (1986) reported high $\mathrm{He}^{3} / \mathrm{He}^{4}$ ratios, indicating that the helium anomalies were derived from magmatic volatiles and that the earthquake activity was of volcanic rather than strictly tectonic origin. Similar studies in California (CraIG et al., 1980; 1981) reported concurrent isotopic and concentration anomalies in thermal springs and suggested that differential mixing of meteoric and deep fluids was responsible for precursory variations in the concentrations of helium and other dissolved gases in these water sources.

Studies of the association between subsurface groundwater radon concentrations and seismic activity have been underway for several decades (SHIRATOI, 1927; IMAMURA, 1947; HATUDA, 1953; OKABE, 1956). Recent monitoring programs have typically employed intermittent sampling from natural springs, shallow groundwater wells, or deep $(2000 \mathrm{~m})$ monitoring wells, and have determined radon concentrations using gas-phase scintillation counting or liquid/liquid extraction of radon and liquid scintillation counting (FrIEDMANN and HERNEGGER, 1978; TALWANI et al., 1980; TENG, 1980, 1984; WAKITA et al., 1980a, 1985; HAUKSSON, 1981a; HAUKSSON and Goddard, 1981; Allegri et al., 1983; Barsukov et al., 1985; ChUnG, 1985; FriedMANN, 1985; KING, 1985a, 1986; LiU et al., 1985; SHAPIRO et al., 1985; SANTOYO et al., 1987). Continuous monitoring of radon activities is now becoming a more accepted method, as the earlier results have shown that radon anomalies are frequently of short duration. This method employs direct alpha particle counting in $\mathrm{ZnS}$ scintillation chambers, or beta and gamma counting of filters impregnated with the radon daughter products (Pb214, Pb210, Po214, and Bi214) (SMITH et al., 1976; Noguchi and Wakita, 1977; Melvin et al., 1978; ShaPIRo et al., 1982, 1985; TENG, 1984; TOMBrello et al., 1984; ChUNG, 1985).

The $M=5.3$ Tashkent earthquake in 1966 produced the first well-documented precursory radon anomaly in which activities in a deep groundwater well showed a nearly threefold increase, spanning a period of at least one year, and peaking at the 
time of the earthquake (Ulomov and MaVASHEV, 1971; Gorbushina et al., 1973). Because of long gaps in the early data set, this anomaly may have lasted for several years. Although several recently reported radon increases have had durations of several months to more than a year and amplitudes of several tens of percent to a few hundred percent above prior background (ZHANG and FU, 1981; ALLEGRI et al., 1983; MeI, 1984; NerSESOv, 1984; FrIEDMANN, 1985; Li et al., 1985; WAKITA et al., 1985; SANTOYO et al., 1987), most have spanned periods of a few hours to a few days (ChALOV et al., 1977; BARsuKov et al., 1979a, 1985; TALWANI et al., 1980; Teng, 1980, 1984; Hauksson, 1981b; Hauksson and Goddard, 1981; TalwanI, 1981; Teng et al., 1981; WaKita, 1982; CaI et al., 1984; Zhu et al., 1984; ChUng, 1985; LI et al., 1985; LiU et al., 1985; SANToYo et al., 1987). Some studies have also suggested that short-term decreases in radon activity should be considered to be earthquake precursors (TALWANI et al., 1980; WAKITA, 1981, 1984; CAI et al., 1984). In at least two cases (CAI et al., 1984; SANTOYo et al., 1987), a decline in radon activity at one water source was contemporaneous with an increase in a second one.

Radon anomalies, possibly associated with volcanically induced earthquake activity, have been shown to occur in thermal wells and in fumarolic discharges by several investigators (CHIRKov, 1975; GaSPaRINI and MonTovanI, 1978; Hauksson, 1981b). A related study conducted on Vulcano Island (Italy) (Del Pezzo et al., 1981), showed that such anomalies can also occur in shallow, nonthermal, groundwater supplies. This study showed radon increases that occurred prior to the volcanic activity, whereas the former reported both precursory and contemporaneous radon variations.

The occurrence of hydrogen anomalies on fault systems has been recognized only relatively recently. NAGATA (1979) found a strong hydrogen response in both shallow and deep groundwaters to a micro-earthquake swarm on the Izu Peninsula (Japan); he also reports a weaker response to the later 1978 Izu-Oshima-Kinkai earthquake. SUGISAKI et al. (1980), in an analysis of soil and spring gases, determined highly variable concentrations of hydrogen, and other gases, within and between faults, depending on rock type and on fault activity. This study also found greater enrichment of hydrogen in soil gases (see following) than were typically found in groundwater discharges.

The application of hydrogen as an indicator of impending seismic activity was prompted by the detection of hydrogen anomalies, either prior to or contemporaneous with seismic activity (NAGATA et al., 1979; Li et al., 1985; SUGISAKI, 1985; SUGISAKI and SUGruRA, 1986). Monitoring programs typically employ discrete sampling of gas from groundwater and subsequent analysis by gas chromatography. Results of these efforts have shown variable hydrogen enrichments, but there is little agreement regarding the timing or amplitude of the anomalies and the associated seismic events. Whereas SUGISAKI (1985) found a general correlation between the hydrogen concentrations observed and earthquake magnitudes along a particular 
fault, other investigators have found no clear relationship between the anomalies and the magnitude or the intervening distance of seismic activity.

\section{Environmental interferences}

A common element in all the investigations of groundwater geochemical precursors has been the difficulty in differentiation between true earthquake precursors and background noise. The environmental conditions that produce the largest variations in groundwater ion concentrations have been seasonal changes in the rates. of recharge and groundwater pumping. Although relatively little detailed research has been conducted on these effects, most studies attempt to minimize them by sampling only from deep wells or springs that are fed from deep aquifers (CAI $e t$ al., 1984; LI et al., 1985).

Analysis of secondary impacts on dissolved gas anomalies has been more intensive. Groundwater pumping has been shown to either increase or decrease radon activities (TENG et al., 1981; KING, 1985a; WAKITA et al., 1985), but increased rates of rainfall were usually found to depress radon activities (TALWANI et al., 1980; TENG et al., 1981; CAI et al., 1984; WAKITA et al., 1985). Other studies have shown that rainfall does not exert a significant influence over radon activities at depth, if a monitoring well is of sufficient depth or is hydraulically isolated from surface aquifers (WAKITA et al., 1985). Barometric pressure changes reportedly have a relatively modest effect on groundwater radon in most cases (WAKITA, 1984; WAKITA et al., 1985), but if declining pressures result in supersaturation of another dissolved gas, the trace gases can be stripped from groundwaters, resulting in large and erratic variations (SUGISAKI et al., 1980; KAWABE et al., 1981; SHAPIRO et al., 1982, 1985). Other effects that produce nonprecursory changes in gas concentrations include: dilution by biogenic methane or carbon dioxide (SUGISAKI, 1978), earth-tide effects (SUGISAKI, 1980; WAKITA, 1984; WAKITA et al., 1985; SUGISAKI and SUGIURA, 1986) and thermo-elastic strain changes (SHAPIRo et al., 1985). Although most studies have dealt with these interferences on an ad hoc basis, Shapiro and coworkers have employed spectral analysis techniques in order to clearly identify the impact of each effect and thereby differentiate between true precursory anomalies and chemical changes that are due to nonseismic effects (SHAPIRo et al., 1985).

\section{Ground-Gas Geochemical Anomalies}

During the last several years a number of investigators have begun monitoring the concentrations of trace gases in 'soil air.' Radon and hydrogen have been the focus of most of this work, although a few studies have also investigated ground gas helium as an earthquake precursor. 
The association between earthquakes and anomalies in ground gas radon concentrations has been intensively investigated for more than 30 years (see reviews by TANNER, 1964; 1980 and KING, 1980a; 1980b; 1985a; 1986). These studies typically measured integrated average radon activities in the shallow ( $<2 \mathrm{~m}$ depth) soil layer, using nitrocellulose films (FLeISCHER and MOGRo-CAMPERO, 1978; CoX et al., 1980; TALWANi et al., 1980; SteEle, 1981, 1985; ThOMAS et al., 1986) or less temperaturesensitive allyl diglycol carbonate chips (FLEISCHER and Mogro-CAMPERo, 1985). The low sensitivity of these detectors requires averaging times of one to three weeks, depending upon soil radon concentrations. Hourly averaging intervals have been achieved in other studies using ionization chamber pulse counting devices (YAMAUCHI and SHIMO, 1982) or field portable electronic semiconductor detection equipment (KING, 1985b; ThOMAS and KoyanaGi, 1986). Gamma counting of radon daughter products in the soil horizon has also been employed to determine long-term average profiles of subsurface radon (FERNANDEZ, 1983; KuRATA and TSUNOGAI, 1986).

The most frequently reported precursory radon anomalies have been increases in activities prior to, or contemporaneous with, seismic events. The apparent durations of the radon anomalies ranged from a few hours, using the semiconductor detectors (KING, 1985b), to periods of weeks or months (FleisCHER and MOGRo-CAMPERo, 1985; Tномаs et al., 1986). Anomaly amplitudes have ranged from an increase of a factor of two above prior backgrounds (KING, 1978; TALWANI et al., 1980; STEEL, 1981, 1985; ABDUVALIYEV et al., 1984) to increases of factors of ten or greater (KING, 1978, 1985b; Mogro-Campero et al., 1980; Thomas et al., 1986). In one case (FleisCher and Mogro-CAMPERo, 1985), decreases in radon activity by factors of more than 500 were attributed to seismic effects. Anomaly amplitudes appear to be at least partly controlled by the integration period: hourly integrations showed 'spike-like' anomalies exceeding prior averages by factors of five to ten, but longer integrations typically showed broader, less intense, increases.

Some investigators have suggested that the intensity of the radon anomaly declines with increasing distance between a monitoring station and the epicenter of the earthquake and with decreasing magnitude of the event (KING, 1978; BIRCHARD and LibBy, 1980; FleisCher and Mogro-CAMPERo, 1985; Thomas et al., 1986); however, others have encountered highly nonlinear radon anomalies in which distant earthquakes produced stronger responses than did those located closer to the monitoring station (Fleischer and Mogro-CAMPERo, 1985; STEEL, 1985; King, 1986). The period between precursory anomalies and associated earthquakes generally ranged from several days prior to the earthquake in question (KING, 1978, 1985b; Talwani et al., 1980; Abduvaliyev et al., 1984; ThOmas et al., 1986; Santoyo et al., 1987) to as long as several months (BIRCHARD and LiBBY, 1980; STEELE, 1981, 1985). In some cases, anomalies have also occurred contemporaneously with, or after, the events (BIRCHARD and LiBBY, 1980; KING, 1985b; ThOMAS et al., 1986).

Studies on Kilauea have found that ground gas radon anomalies can also accompany volcanic activity. KING (1980) reported a correlation between radon 
concentrations and seismic activity associated with an eruption and, more recently, other investigators (Cox et al., 1980; Cox, 1983; Thомas et al., 1986; ThомаS and KOYANAGI, 1986) have suggested that thermal changes or deformation can produce radon anomalies that are contemporaneous with the onset of intrusive or eruptive activity.

Recent analyses of hydrogen in fault gases have shown that hydrogen can be enriched in these gases by more than four orders of magnitude above that present in air (SUGISAKI et al., 1980; 1983; WAKITA et al., 1980b). Repeated analyses at narrowly spaced sampling points along these faults found orders of magnitude variation in concentrations from place to place and over short time intervals. Both groups of investigators have postulated that a genetic relationship exists between fault activity and hydrogen generation. SugISAKI et al. (1983) have also suggested that a correlation exists between the age of fault activity and hydrogen concentrations, but that the rock type and degree of alteration can affect the concentrations of hydrogen present, regardless of the age of activity. WARE et al. (1985) confirmed the latter result in hydrogen surveys on several fault systems, both inactive and very recently active, but found little correlation between age of activity and hydrogen content. They suggest that both hydrothermal activity and oxidation of iron hydroxide are capable of generating strong enrichments of hydrogen, independent of age of movement on a particular fault. Isotopic analysis of hydrogen in fault gases (KITA et al., 1980) indicated that its depth or origin was $20 \mathrm{~km}$, or possibly much less, suggesting a relatively shallow origin for the hydrogen.

Hydrogen concentrations have been monitored for precursory variations in a number of fault systems, using either discrete sampling and laboratory analysis (SUGISAKI, 1985; SUGISAKI and SUgIURA, 1986) or continuous monitoring of ground gas, using hydrogen-sensitive fuel cells (SATo and MCGEe, 1981; SATo et al., 1985; 1986). Results suggest that increases in hydrogen concentrations can occur either prior to or contemporaneous with seismic activity. SUGISAKI (1985) also reports a general correlation between hydrogen concentrations and earthquake magnitudes, but SATAKE et al. $(1985)$ and SATo et al. $(1985,1986)$ find more variable hydrogen responses to both the magnitude and intervening distance of earthquakes and creep events.

Ground gas helium concentrations, as earthquake precursors, have been most intensively studied by REIMER $(1980,1981,1985)$, who has reported apparent decreases in its concentration prior to earthquakes in California. During a fifty-four month study period, fifteen of eighteen individual earthquakes or earthquake clusters were preceded by helium anomalies. WAKITA (1978) reports high helium concentrations associated with a volcanic earthquake swarm; elevated isotopic ratios of the anomalous helium suggest that its source was magmatic volatiles released by a rising diapir. 


\section{Environmental interferences}

Even though soil gas concentrations are not as sensitive to hydrologic changes as groundwater chemistry is, they are extremely susceptible to a number of other environmental effects. Natural variations of radon in ground gases have been the most intensively researched during the last several decades, and have been reviewed by TANNER $(1964,1980)$. Because of its effect on the exchange rate of air with subsurface gases, one of the most important factors that controls the concentration of crustal gases in the ground is the soil permeability. Soil morphology and such factors as frozen or rain saturated ground can produce orders of magnitude spatial and temporal variations in soil gas concentrations (KovaCH, 1946; KRANER et al., 1964; Guedalia et al., 1970; Megumi and Mamuro, 1973; Mochizuki and SekiKaWa, 1980; Reimer, 1980; FincK and Pearson, 1981; Klusman, 1981; Klusman and WeBster, 1981; YAMAUCHI and SHIMO, 1982; FleisCher, 1983; RoBINSON and WhiteHEAD, 1986). Soil moisture also has a more specific influence on radon concentrations due to recoil-implantation and diffusional effects (TANNER, 1980; FLeISCHER, 1983). Several investigators also report that diurnal and synoptic barometric pressure changes can influence shallow gas compositions by pumping air into the ground or drawing soil gases out of the ground (HATUDA, 1953; KRANER et al., 1964; KLUSMAN, 1981; Klusman and WebSTER, 1981; SCHERY et al., 1982); wind speed and turbulent pumping can generate similar effects on ground gas compositions (KRANER et al., 1964; Pearson and Jones, 1965; Guedalia et al., 1970; IsRaelsSon, 1980; Reimer, 1980). There is, however, no general agreement as to the relative importance of these effects in the detection of ground gas precursors; some studies report significant diurnal and meteorological interferences (FLEISCHER and MOGRO-CAMPERO, 1978; King, 1985b; Reimer, 1985; SATo et al., 1986), others have found none (FleisCher and Mogro-CAMPero, 1985; Thomas et al., 1986). Although these differences may be the result of variations in monitoring protocol or in local soil and meteorological conditions, their occurrence suggests that meteorological effects need to be considered in a ground gas precursory monitoring effort.

\section{Analysis of Mechanisms Responsible for Geochemical Anomalies}

Because the underlying phenomena associated with the earthquake preparation process are physical in nature, it is clear that a physical mechanism must underlie the precursory chemical anomalies that have been observed. Although many nominally different mechanisms have been proposed to account for geochemical precursors, most are based on one of the following processes:

1. Physico-chemical release by ultrasonic vibration (UV model);

2. Chemical release due to pressure sensitive solubility (PSS model);

3. Physical release by pore collapse (PC model); 
4. Chemical release by increased loss from, or reaction with, freshly created rock surfaces (IRSA model)

5. Physical mixing due to aquifer breaching/fluid mixing (AB/FM model).

These processes are supported, to some degree, by the available field or laboratory data. A careful examination of each, in terms of its ability to account for the reported anomalies and its consistency with what is known of the earthquake preparation process, should enable us to identify which of these mechanisms can best account for the wide range of chemical precursors observed.

\section{Ultrasonic vibration model}

Several investigators (MAVLYANOv et al., 1971; ChAlov et al., 1977; BARSUKov et al., 1979a, 1979b, 1985) have suggested that loosely bound elements or compounds in subsurface rocks can be mechanically freed by ultrasonic vibrations that are postulated to occur prior to seismic events. Laboratory studies have shown that rocks react more rapidly with water when exposed to ultrasonic treatment (BARSUKOv et al., 1985) and other investigations have shown that groundwater chemical anomalies can be artificially induced by nearby explosive discharges (CAI et al., 1984; BARSUKov et al., 1985).

In spite of this apparently supportive data, it is questionable whether ultrasonic vibrational energy can account for the majority of the reported chemical earthquake precursors. The increased reactivity of rock surfaces under ultrasonic treatment in the laboratory is more likely the result of cavitation and enhanced mixing at the rock-water interface at the extremely high rates of energy applied. Field data also show that the high-frequency component of micro-earthquakes that might conceivably generate this ultrasonic vibration (TENG, 1984; TENG and HENYEY, 1984) is far weaker than that applied experimentally and is therefore unlikely to contribute significantly to the release of ions or gases from subsurface rocks. Similarly, the explosion-induced changes in groundwater chemistry were much smaller than many reported chemical precursors and were delayed by several hours after the explosions occurred (BARSUKov et al., 1985; Li et al., 1985). This delay clearly suggests that the increases in ion concentrations were generated by something more than the vibrations alone. On this basis, it is considered unlikely that simple vibrational release of ions and gases from the subsurface rock matrix is responsible for the observed geochemical precursors.

\section{Pressure sensitive solubility model}

The sensitivity of ion and gas solubilities to changes in fluid pressure is well established (HELgESON, 1969; KHARAKA and BARNES, 1973) and it has been suggested that precursory stress changes can increase the concentrations of a variety of dissolved species in groundwater (CAI et al., 1984). An analysis of hydrologic anom- 
alies that accompany stress changes suggests that this mechanism is unlikely to contribute significantly to changes in fluid chemistry. The pressures needed to change ion solubilities by a significant factor (e.g., $50 \%$ ) are on the order of tens to hundreds of bars. Even though a stress change of this magnitude may be associated with rock fracture, there is little evidence that such changes are transmitted to the fluid phase. Groundwater head levels and flow rates, which would reflect subsurface pressure variations, have typically been on the order of a few bars or less (CAI et al., 1984; WANG et al., 1984), and many groundwater precursors have been accompanied by no detectable head changes. Although dissolved gas concentrations are more sensitive to pressure changes, most reported anomalies involve gases $\left(\mathrm{H}_{2}, \mathrm{He}, \mathrm{Rn}\right)$ that are well below saturation and are therefore insensitive to the small changes in hydrostatic pressure that do occur. The effects of pressure sensitive solubility on dissolved ion and gas concentrations are thus not indicated to play a significant role in precursory geochemical anomalies.

\section{Pore collapse model}

The pore collapse (PC) model has been suggested to account for increases in the concentration of dissolved ions in groundwater (BARSUKov et al., 1979b; 1985; JIANG and LI, 1981b; Li et al., 1985), changes in the absolute and relative concentrations of dissolved gases in groundwater (SUGISAKI, 1978; BARSUKov et al., 1979b, 1985; SUGISAKI and SUGIURA, 1986), and increases in radon concentrations in shallow ground gases (KING, 1978, 1980b, 1985b; MOGRO-CAMPERo et al., 1980; FleISCHER and MOGRo-CAMPERo, 1985). Its basic rational is that, at increasing stresses prior to an earthquake, the pre-existing pore volume collapses and expels chemically distinct pore fluids into the circulating groundwater system, generating a chemical anomaly. Collapse of pore volume in the vadose zone is believed to generate an upflow of ground gas that displaces the normal radon concentration gradient in the shallow soil layer.

Loss of pore volume in rocks exposed to stress has been demonstrated in several laboratory studies (ZOBACK and BYERLEE, 1975b; BRACE, 1977, 1978a, 1978b; BYERLEE, 1978). These studies have shown that unconsolidated materials and fault gouge display the greatest volume changes, but that sandstone (BRACE and RiLEY, 1972) and tuffs (HoNDA et al., 1982) also undergo significant losses as well. Field evidence supporting this mechanism includes cyclic changes in inert gas ratios associated with tidal strain variations (SUGISAKI, 1978; SUGISAKI and SUgIURA, 1986) and explosion induced radon anomalies. The latter study reported a decline in the amplitude of the anomalies with repeated events, suggesting that the locally produced radon was gradually being exhausted from the pre-existing pore volume (BARSUKov et al., 1985).

The significance of the PC model to precursory earthquake phenomena is open to question on several counts. Laboratory data show that volume losses in most competent rocks occur at relatively low stress levels and are usually quite small; at 
higher stresses pore volume increases in most rocks and, in some cases, can exceed that intitially present (BRACE, 1978a). More porous rocks typically show greater volume losses; this decline is irreversible and is unlikely to account for repeated precursory anomalies or cyclic chemical changes in groundwater. Investigation of gas emanation from rocks shows that gas release declines at low to intermediate stresses, due to closure of the channels through which gases escape, and only at higher stresses does gas emanation increase appreciably (HOLUB, 1981; GIARDINI et al., 1976; Holub and Brady, 1981; Honda et al., 1982). The latter increase is accompanied by acoustic emissions associated with micro-fracturing and is believed to be the result of new pore volume formation associated with dilatency (SOBOLEV, 1984; VARSHAL et al., 1985). The pore collapse model is not likely to be a major factor in the precursory groundwater chemistry anomalies that have been observed.

The application of the PC model to precursory ground gas radon anomalies is subject to additional uncertainties. Radon activities in near-surface soil gas are controlled by specific emanation rates, radioactive decay, diffusive loss to the air column, and dilution by downward mixing of air. The interaction of these effects produces an increasing radon concentration gradient from near zero at the soil-air interface to an equilibrium concentration at depth. The PC model suggests that pore collapse expels gases from subsurface rocks and generates an upward flow of gas that displaces the equilibrium soil radon profile and is detected as an apparent increase in shallow soil radon activities. Studies by KRANER et al. (1964) and more recent investigators (Clements and Wilkening, 1974; FleisCher and MogroCAmpero, 1978; Mogro-Campero et al., 1980; TANNER, 1980; Kurata and Tsunogai, 1986) show, however, that radon profiles in most soils approach equilibrium exponentially and reach maximum concentrations at depths of two to three meters. Radon activities at depths of $0.5 \mathrm{~m}$ to $1.0 \mathrm{~m}$, under no-flow conditions, are typically about half the equilibrium concentrations. Upward flow of ground gas, regardless of rate, can therefore only increase the detected radon concentration by a factor of two or three; however, several precursory anomalies have been detected at depths of $0.5 \mathrm{~m}$ to $1.0 \mathrm{~m}$ that were higher than long-term average activities by factors of five to ten (Fleischer and Mogro-CAMPero, 1985; King, 1985b; ThOMas et al., 1986; THOMAS and KoYANaGi, 1986). Similarly, surface winds, which are known to produce an upward flow of ground gas (WoODCOCK, 1987; WOODCOCK and FRIEDMAN, 1979), have not generated activity variations of magnitudes similar to those associated with earthquake precursors (THомAs, unpublished data). It is considered unlikely that pore collapse, and resultant upward migration of ground-gas, can account for large precursory radon increases.

\section{Increased reactive surface area model}

Several investigators have proposed that micro-fracturing prior to major seismic events is responsible for precursory increases in ion and gas concentrations 
(HAuksSon, 1981a; WaKita, 1982; CaI et al., 1984; Sugisaki et al., 1983; ThOMAS et al., 1986). The exposure of fresh silicate surfaces, resulting from mineral fracture, is believed to both increase the rate of alteration reactions with groundwater and to allow the escape of trapped gases from the rock matrix.

Laboratory studies of whole or jointed rocks have shown that dilatancy and pervasive microfracturing can increase porosities from $20 \%$ to as high as $400 \%$ prior to failure (ZOBACK and BYERLEE, 1975a, 1975b; BRACE, 1977, 1978a, 1978b; BYERLEE, 1978; WANG et al., 1978; SoBolev, 1984; SoBolev et al., 1984). Dissolution or alteration of fresh rock surfaces could significantly increase ion concentrations present in groundwater and would be especially noticeable in well-established aquifers where older rock surfaces have been passivated by the formation of equilibrium alteration assemblages. As noted previously, laboratory studies have shown that the rate of gas release from rocks is enhanced at stress levels associated with microfracturing (HoluB and BRADY, 1981; SOBOLEv et al., 1984; KATOH et al., 1985). Field investigations have reported coincident trends in regional stress changes and groundwater radon concentrations (WAKITA et al., 1985), and in regional deformation changes and ground gas radon activities (THOMAS and KoYANAGI, 1986). It is therefore suggested that radiogenic and other trapped gases (e.g., $\mathrm{He}, \mathrm{Ar}, \mathrm{Rn}, \mathrm{CO}_{2}, \mathrm{CH}_{4}$, or $\mathrm{H}_{2} \mathrm{~S}$ ) within the rock matrix are released by microfracturing associated with regional stress changes accompanying the earthquake preparation process.

Extension of the increased reactive surface area (IRSA) model to include hydrogen, which is not normally present in the rock matrix at high concentrations, requires further explanation. This has been provided by Kita and others (KITA et al., 1980; KITA and MATSUO, 1982; SUGISAKE et al., 1983) who have shown that silicate radicals created by the fracture process are capable of producing significant quantities of hydrogen. Observations of hydrogen spectra generated by water-saturated rocks during fracture (BRADY and Rowell, 1986) and isotopic data that suggested that hydrogen had been lost during a precursory episode due to water-rock reactions (O'NeIL and KING, 1981) further substantiate this mechanism.

Other mechanisms proposed to explain these anomalies do not seem as well supported. Oxidation of iron minerals (WARE et al., 1985) may explain long-lived sources of fault hydrogen, but cannot easily account for the episodic nature of some of the anomalies observed (Sugisaki and Sugiura, 1986). Release of deep-seated hydrogen due to dilation of a fault by serpentinization of deep crustal rocks (SATo et al., 1985, 1986) is also open to question. The anomalies typically observed during the latter studies consisted of short duration spikes against a background of undetectable ambient hydrogen concentrations. Because of hydrogen's high diffusion rate, its periodic release from the base of the crust would be expected to produce much broader anomalies against a low, but still measurable, background. The occurrence of anomalies in association with creep events on the San Andreas fault which, on the basis of geophysical data, are believed to be near surface events (R. SIMPSON, oral communication), further suggests a shallow, rather than deep, hydrogen source. 
Uncertainties have, however, been raised about the IRSA model because many of the laboratory investigations of rock dilatancy show that microfracturing becomes significant in rocks only as its failure strength is approached. On this basis, it is generally accepted that the preseismic dilatant zone is confined to a small volume surrounding the impending hypocenter and does not extend into the far field where many of the geochemical anomalies occur (Scholz et al., 1973; MoGI, 1977; RICE and RUDNICKI, 1979; SCHOLZ, 1987). It can be argued, however, that more realistic models of rock fracture under field conditions are those observed in studies of stress corrosion cracking (ANDERSON and GREw, 1977) and subcritical crack growth (ATKINSON, 1984) in which fracture propagation is observed at very slow strain rates and under moderate to high levels of humidity. These investigations have shown that crack propagation rates are highly dependent on moisture content and stress rates and, more importantly, that subcritical fracture growth continues at stress levels that are less than $20 \%$ of those required for catastrophic failure (MEREDITH and AtKinson, 1983; Atkinson, 1984; Freiman, 1984). Recent papers by Crampin $e t$ al., (1984) and CrAMPIN (1987) have suggested that several geophysical earthquake precursors could be explained by pervasive subcritical crack growth and I would suggest that this same phenomenon could also account for many of the dissolved gas and ground gas chemical anomalies that have been observed at substantial distances from an impending earthquake. The contribution of the IRSA model to precursory changes in dissolved ion chemistry is, however, likely to be limited because of the slow reaction rate of most minerals with groundwaters.

\section{Aquifer breaching/fluid mixing model}

Precursory changes in groundwater chemistry are often attributed to mixing of fluids from two or more chemically distinct aquifers. This mechanism has the advantage of being able to account for not only increases in dissolved ion or gas concentrations (CAI et al., 1984; LI et al., 1985), but also for concentration decreases (KING et al., 1981; WAKITA, 1982; BARSUKov et al., 1985) and for concurrent temperature changes that accompany chemical anomalies (CRAIG et al., 1981; KING et al., 1981; WAKITA 1982, 1984). The precise mechanism of fluid mixing is most often suggested to be precursory fracturing of hydrologic barriers between isolated aquifers that allows them to subsequently mix (SIBSON, 1981; BarSUKov et al., 1985; CAI et al., 1984; Li et al., 1985).

Because the characterization of chemically distinct water sources requires analytical data for several different ions or isotopes, a clear demonstration of the mixing hypothesis has seldom been achieved. The two studies which best demonstrate groundwater mixing are those of CraIG et al. $(1980 ; 1981)$ and King and others (KING et al., 1981; O'NeIL and KING, 1981). Craig's investigation used gas concentrations and isotopic abundances to show that several thermal springs and wells discharged mixtures of deep crustal fluids and shallow meteoric components, 
and that precursory changes in fluid compositions were the result of increasing contributions of the deep component to the total flow. King and coworkers suggested a similar conclusion from dissolved ion and hydrogen and oxygen isotopic data. Several other monitoring programs, although not reporting full data sets, have shown that coincident changes in chemical composition, temperature, and water level or flow rate often occur (JIANG and LI, 1981a, 1981b; WAKITA 1981, 1982, 1984; MEI, 1984; ZHU et al., 1984; BARSUKOV et al., 1985; Li et al., 1985). The reported anomalies include examples of falling chloride and cation concentrations that are accompanied by decreasing temperatures and increasing flow rates or water levels (JIANG et al., 1981a; CAI et al., 1984; LI et al., 1985), or declining radon concentrations that are accompanied by falling temperatures (WAKITA et al., 1980a; WAKITA, 1982, 1984). Hence, the chemical and hydrologic observations strongly suggest that mixing of chemically distinct groundwaters is the predominant effect responsible for many of the decreases in ion concentrations as well as the substantial increases in dissolved ion concentrations observed.

The physical mechanism responsible for the mixing of fluids is, however, not well established. Laboratory investigations have shown that rock porosities increase substantially when loaded to near their failure stress (ZOBACK and BYERLEE, 1975a; BRACE, 1977, 1978a, 1978b, BYERLEE, 1978); however, resistivity and permeability changes indicate that most of the fracture porosity created is not interconnected (ZOBACK and BYERLEE, 1975a, 1975b; WANG and MORRISON, 1975; WANG et al., 1978) and that the absolute increase in matrix permeability is still very small (BRACE, 1978a, 1978b). Other investigations, conducted on jointed or artificially saw-cut samples, have reported increases or decreases in fluid flow through existing fractures of several hundred percent, in response to small changes in stress normal to, or parallel to, the joint face (BraCE, 1978a, 1978b; BYERLEE, 1978). The permeability response of clays or other fault-gouge materials to changes in stress, and their impact on these results is, as yet, unclear (BRACE, 1978a; BYERLEE, 1978). Nonetheless, the question of whether far-field stress changes would be sufficient to generate the permeability changes required to allow large scale mixing of groundwaters remains a serious impediment to the general application of this model.

Other uncertainties about this mechanism include how such mixing could be accomplished without massive displacement of groundwaters, and how aquifer breaching could account for episodic precursors that show short-term concentration changes that subsequently return to normal baseline levels. Significant questions still remain regarding the ability of far-field stress changes to effect broad scale fluid mixing between separate aquifers.

An alternative physical mechanism that I believe might more effectively account for groundwater chemical precursors is based on the changes in hydraulic head that have been observed in wells prior to, or concurrent with, some earthquakes (ROELOFFS and BREDEHOEFT, 1985; ROELOFFS and RUDNICKI, 1985, 1986; ROELOFFS, 1987). The physical and chemical composition of a mixed fluid discharged from a 
well or spring that draws fluids from two or more chemically and thermally distinct aquifers is critically dependent upon the hydraulic head within each aquifer. A change in the relative pressures among the aquifers, brought about by a precursory stress change, could substantially alter the discharge chemistry without requiring large scale mixing of fluids away from the fluid discharge conduit. An attractive feature of this mechanism is that it can account for episodic anomalies and for cyclic variations in fluid chemistry that have a tidal frequency (SUGISAKI, 1980; SUGISAKI and SugIURA, 1986); earth-tide driven fluctuations in hydraulic heads of subsurface aquifers have been widely documented (ROELOFFS and BREDEHOEFT, 1985; ROELOFFS, 1987). Such fluctuations could generate periodic chemical variations in spring discharges for an indefinite period of time, without causing progressive or irreversible changes in the up-flow zone, as would be required by the PC and IRSA models.

The field and laboratory data suggest that fluid mixing can account for precursory changes in water chemistry as well as associated changes in temperature, flow rate, and water level that have been widely observed. Although the precise mechanism that produces these changes has not been established, it is suggested that variations in differential hydraulic head between distinct feed zones may account for episodic and cyclic changes, but that permanent or long-term changes in the physical (e.g., temperature, flow rate, head pressure) or chemical characteristics of a water source may be the result of barrier breaching between formerly separate aquifers.

\section{Summary}

The models that seem best able to account for the reported precursory geochemical and hydrologic anomalies are the increased reactive surface model and the aquifer breaching/fluid mixing model. The former can account for many of the gas concentration anomalies that have been reported, but only for modest increases in ion concentrations. The latter best explains the major changes in ion and isotope chemistry, as well as associated variations in water level, flow rate, and temperature that have been observed. Models invoking ultrasonic vibration, pressure sensitive solubility, and pore volume collapse seem less able to explain the range of chemical anomalies that have been detected in precursor monitoring programs.

\section{Application to Earthquake Forecasting}

Even though the above mechanisms appear to account for precursory phenomena, a major remaining question is how, or whether, geochemical precursors can be used to forecast inpending earthquakes. Several researchers have claimed that the timing, rise time, magnitude, or distribution pattern of precursory anomalies can be 
used to predict the location, timing, and magnitude of future earthquakes; none of these claims has held up under close scrutiny or, more importantly, to a test of reproducibility. The reasons for this can be attributed in part to the mechanisms responsible for the anomalies and in part to the protocols followed in the geochemical monitoring programs and interpretation of the data gathered.

Examination of the aquifer breach/fluid mixing model shows why attempts to extract earthquake magnitude information directly from the magnitude of geochemical anomalies is destined to failure. Even if the extent of fluid mixing accompanying stress induced changes in aquifer head or flow rate were a function of the magnitude of the stress changes, the resultant impact on a water source will be strictly a function of the heads and fluid compositions of the aquifers; extensive mixing of fluids having identical compositions cannot produce a chemical anomaly, whereas only minor changes in the relative flow rates of two markedly different aquifers will generate substantial changes in the composition of a mixed discharge. Prediction of the magnitude of an impending earthquake on the basis of the intensity of observed geochemical anomalies would, therefore, require a complete knowledge of the chemical and hydrologic characteristics of all aquifers that interact with the water source being monitored.

Even if the uncertainties of fluid mixing could be resolved, there is the larger issue of how precursory stress/strain changes are distributed around the hypocenter of an impending earthquake, and how these stresses are translated to the hydrologic system. Some of the simpler models of stress distributions around an impending epicenter (DoBrovolsky et al., 1979; FleISCHER, 1981) show complex distributions of compressional and dilational stress in the far field that, when imposed on a hydraulic system, could have effects that will be very difficult to interpret without an excessive monitoring effort. More importantly, these theoretical models have only been able to evaluate stress/strain fields around faults as though the surrounding volume is an isotropic, homogeneous, half-space. It clearly is not; subsidiary faults, elevation changes, and variable shapes and orientations of asperity volumes will all have profound effects on stress distribution patterns around a hypocenter. Hence the expectation of a uniform, predictable, distribution of precursory hydrologic and fluid chemistry anomalies around an asperity volume is unrealistic given the complexities of multiply faulted terrain.

Anomalies in the concentrations of hydrogen and radon in ground-gas are not believed to be as sensitive to hydrologic variables as groundwater chemistry variations are. Nonetheless, they are subject to the same uncertainties of distribution and transmission of the stress/strain field and to interferences from environmental variations. Even though ground-gas variations may not have the inherent unpredictability of the response of groundwater chemistry anomalies, their interpretation is still far from straightforward.

In spite of these difficulties, useful data can be obtained from presursory geochemical variations. In order to best extract this information, it will be necessary 
to institute a long term, continuous (rather than an intermittent) monitoring program of several geochemical and hydrologic variables. This effort should include analyses of water head pressures, temperatures, ion and dissolved gas chemistry and groundgas chemistry. The regional choice of a monitoring station should be based upon geophysical considerations of where significant seismic events are likely to occur, but site specific locations should attempt to maximize sensitivity to seismic stress changes and minimize sensitivity to surface effects. Analysis of the data generated should include statistical pattern recognition and Fourier, or other spectral, analysis techniques such as that applied by SHAPIRO et al. (1985). In order to alleviate the currently unknown manner in which the anomalies are likely to be distributed around an impending epicenter, the monitoring program would have to be broadly based and, as the sensitivity, or lack thereof, of various sites is determined, the distribution of monitoring stations should be modified accordingly.

A monitoring program similar to that outlined above, when conducted concurrently with a broad-based geophysical monitoring program, should be able to detect both geologically anomalous conditions - such as those associated with creep events or preseismic stress changes-as well as nongeologic interferences that may impede the identification of preseismic conditions. The identification of geologically anomalous conditions would make it possible to then forecast the probability of a seismic event in a given region. The absolute prediction of the precise location and time of a seismic event, using either geochemical or geophysical methods, is considered unlikely until many of the current uncertainties related to the geologic structure of a given area and its probable response to a changing stress field, can be resolved.

\section{Acknowledgements}

The reviews and helpful comments by Bill Evans, Evelyn Roeloffs and Ed Berg, Mike Reimer, Ken McGee, C. -Y. King and an anonymous reviewer are gratefully acknowledged. I would also especially like to thank Drs. K. Aki and W. Stuart for offering me the opportunity to participate in the Conference on the Physical and Observational Basis for Intermediate Term Earthquake Prediction, for which this paper was prepared. HIG Contribution: 1936

\section{REFERENCES}

Abduvaliyev, A. K., Andreyev, V. K., Voytov, G. I. and Sergeyev, R. K. (1984), Time pattern of radon content in the subsoil in the seismically active zones of Western Fergana before the earthquake of 18 October, 1980 and the Nazarbek earthquake of 11 December, 1980. Doklady Akademiyi of Sciences, USSR, Earth Sciences Section, 271,1-3.

Allegri, L., Bella, F., Della Monica, G., Ermini, A., Improta, S., Sgrigna, V. and Biagi, P. F. (1983), 
Radon and tilt anomalies detected before the Irpinia (South Italy) earthquake of November 23, 1980 at great distances from the epicenter. Geophys. Res. Lett. 10, (4), 269-272.

ANDERSON, O. L. and GREW, P. C. (1977), Stress corrosion theory of crack propagation with applications to geophysics. Reviews of Geophysics and Space Physics 15, 77-104.

ATKINSON, B. K. (1984), Subcritical crack growth in geological materials. J. Geophys. Res., 89 (B6), 40774114.

BaRsukov, V. L., VARShAL, G. M. and ZAMOKINA, N. S. (1985), Recent results of hydrogeochemical studies for earthquake prediction in the USSR, PAGEOPH 122, 143-156.

Barsukov, V. L., Varshal, G. M., Garanin, A.V. and Serebrennikov, V. S. (1979a), Hydrogeochemical earthquake precursors. International Symposium on Earthquake Prediction, UNESCO, Paris, April 26, 1979, Sc-79/Conf. 801 Col. 14/1, 1-19.

Barsukov, V. L., Serebrennikov, V. S., Varshal, G. M. and Garanin, A. V. (1979b), Geochemical methods for earthquake prediction. Geokhimiya. 3, 323-337.

Barsukov, V. L., Belyeyev, A. A., Serebrennikov, V. S., Balkaldin, Yu. A., Urunov, M. Kh. and ARSENYEVA, R. V. (1982), Potentialities of using variational estimations of helium content in thermal waters for earthquake prediction. Geokhimiya. 11, 1614-1620.

BIRCHARD, G. F. and LIBBY, W. F. (1980), Soil radon concentration changes preceding and following four magnitude 4.2-4.7 earthquakes on the San Jacinto Fault in southern California. J. Geophys. Res. 85, B6, $3100-3106$.

BRACE, W. F. (1977), Recent laboratory studies of earthquake mechanics and prediction. U.S. - Japanese seminar on earthquake precursors, Tokyo, Japan, 185-202.

BRACE, W. F. (1978a), Volume changes during fracture and frictional sliding: A review. PAGEOPH 116, 603-614.

BRACE, W. F. (1978b), A note on permeability changes in geologic material due to stress. PAGEOPH 116, $627-633$.

Brace, W. F. and Riley, D. K. (1972), Static uniaxial deformation of 15 rocks to $30 \mathrm{~kb}$. International Journal of Rock Mechanics and Mining Sciences 9, 271.

BRADY, B. T. and Rowell, G. A. (1986), Laboratory investigation of the electrodynamics of rock fracture. Nature 321, 488-492.

BULASHEVICH, YU, P. and BASHORIN, V. N. (1973), On the detection of faults along the Sverdlovsk DSS profile from high concentrations of helium in underground water. Earth Physics 9, 3, 93-100.

Bulashevich, Yu. P., Chalov, P. I., Tuzova, T. V., Alekhina, V. M., Merkulova, K. I. and SVETLICHNAYA, N. A. (1976), The helium content and the ratio of the uranium series isotopes in the water of the North-Kirgizian Fracture Zone. Izvestiya, Earth Physics 1, 78-84.

BYERLEE, J. (1978), A review of rock mechanics studies in the United States pertinent to earthquake prediction. PAGEOPH 116, 586-602.

CAl, Z., Sh, H., Zhang, W., Luo, G., E, X., ShI, X., YANG, H., et al. (1984), Some applications of fluidgeochemical methods to earthquake prediction in China. International Symposium on Continental Seismology and Earthquake Prediction, Seismological Press, 384-395.

Chalov, P. I., Tuzova, T. V. and Alekhina, V. M. (1977), Short-term variations in the radioisotopic parameters of the water in faults in the earth's crust and their relationship to earthquake forecasting. Izvestiya, Earth Physics 13, 8, 567-573.

ChIRKov, A. M. (1975), Radon as a possible criterion for predicting eruptions as observed at Karymysky volcano. Bulletin Volcanologique 37, 126-131.

Chung, Y. (1985), Radon variations at Arrowhead and Murrieta Springs: Continuous and discrete measurements. PAGEOPH 122, 294-308.

CHUNG, Y. -C. (1981), Radium-226 and radon-222 in southern California groundwaters: Spatial variations and correlations. Geophys. Res. Lett. 8, 5, 457-460.

Clements, W. E. and Wilkening, M. H. (1974), Atmospheric pressure effects on radon-222 transport across the earth-air interface. J. Geophys. Res. 79, 5025-5029.

Cox, M. E. (1983), Summit outgassing as indicated by radon, mercury and pH mapping, Kilauea volcano, Hawaii. J. Volcanology and Geothermal Res. 16, 131-151.

Cox, M. E., CufF, K. E. and Thomas, D. M. (1980), Variations of ground radon concentrations with activity of Kilauea volcano, Hawaii. Nature $288,74-76$. 
Craig, H., Chung, Y., Poreda, R., Lupton, J. and Damasceno, S. (1980), Fluid phase earthquake precursor studies in Southern California. Eos, Transactions of the American Geophysical Union (abstracts) 61, $46,1035$.

Craig, H., Chung, Y., Poreda, R., Lupton, J. and Damasceno, S. (1981), Investigation of radon and helium as possible fluid-phase precursor to earthquakes. U.S. Geological Survey Open-file Report no. 81$278,36 \mathrm{p}$.

CRAMPIN, S. (1987), Geological and industrial implications of extensive-dilatancy anisotropy. Nature 328, $491-496$.

Crampin, S., Evans, R. and AtKinson, B. K. (1984), Earthquake prediction: A new physical basis. Geophysical Journal of the Royal Astronomical Society 76, 147-156.

Del Pezzo, E., Gasparini, P., Mantovani, M. S. M., Martini, M., Capaldi, G., Gomes, Y. T. and Pece, R. (1981), A case of correlation between $R n$ anomalies and seismic activity on a volcano (Vulcano Island, southern Tyrrhenian Sea. Geophys. Res. Lett. 8, 9, 962-965.

DikUn, A. V., KoROBEYNIK, V. M. and YANITSKIY, I. N. (1975), Some indications of existence of transcrustal gas flow. Geokhimiya 11, 1724-1730.

Dobrovolsky, I. P., ZuBKov, S. I. and Miachkin, V. I. (1979), Estimation of the size of earthquake preparation zones. PAGEOPH 117, 1025-1044.

Fernandez, P., Quindos, L. S., Soto, J., Villar, E. and Guedalia, D. (1983), A new method for measuring radon exhalation. J. Geophys. Res. 88, C2, 1519-1524.

FinCK, R. R. and PEARSON, B. R. R. (1981), In situ Ge(Li)-spectrometric measurements of gamma radiation from radon daughters under different weather conditions. In The Natural Radiation Environment III, Symposium Proceedings, Houston, Texas, April 23-28, 1978, Rep. CONF-780422, U.S. Dept. of Energy, Washington, D.C., pp. 357-369.

FLEISCHER, R. L. (1981), Dislocation model for radon response to distant earthquakes. Geophys. Res. Lett. $8,5,477-480$.

FLEISCHER, R. L. (1983), Theory of alpha recoil effects on radon release and isotopic disequilibrium. Geochimica et Cosmochimica Acta 47, 779-784.

FLEISCHER, R. L. and MOGRO-CAMPERO, A. (1978), Mapping of integrated radon emanation for detection of long-distance migration of gases within the earth, Techniques and principles. J. Geophys. Res. 83, B7, 3539-3549.

FleisCHER, R. L. and Mogro-CAMPERO, A. (1985), Association of subsurface radon changes in Alaska and the northeastern United States with earthquakes. Geochimica et Cosmochimica Acta 49, 1061-1071.

Freiman, S. W. (1984), Effects of chemical environments on slow crack growth in glasses and ceramics. J. Geophys. Res. 89, (B6), 4072-4076.

FRIEDMANN, H. (1985), Anomalies in the radon content of spring water as earthquake precursor phenomena. Earthquake Prediction Research 1, 179-189.

FriedmanN, H. and HerNegGer, F. (1978), A method for continuous measurement of radon in water of springs for earthquake prediction. Geophys. Res. Lett. 5, 7, 565-568.

GaSPIRINI, P. and MANTovaNI, M. S. M. (1978), Radon anomalies and volcanic eruptions. J. Volcanology and Geothermal Res. 3, 325-341.

Giardini, A. A., Subbarayudu, G. V. and Melton, C. E. (1976), The emission of occluded gas from rocks as a function of stress: Its possible use as a tool for predicting earthquakes. Geophys. Res. Lett. 3, 6, 355358.

GoLD, T. and SOTER, S. (1985), Fluid ascent through the solid lithosphere and its relation to earthquakes. PAGEOPH $122,492-530$.

GorbushinA, L. V., Tyminskiy, V. G. and SPIRIDonov, A. I. (1973), Significance of radiohydrogeological anomalies in a seismically active area for predicting earthquakes. International Geology Review 15, 4, 380-383.

Guedalia, D., Laurent, J. -L., Fontan, J., Blanc, D. and Druilhet, A. (1970), A study of radon 220 emanation from soils. J. Geophys. Res. 75, 2, 357-369.

HATUDA, Z. (1953), Radon content and its change in soil air near the ground surface: Memoirs of the College of Science. University of Kyoto, Series B, XX, 4, Article 6, 285-306.

HAUKsSON, E. (1981a), Radon content of ground water as an earthquake precursor: Evaluation of worldwide data and physical basis. J. Geophys. Res. 86, B10, 9397-9410. 
Hauksson, E. (1981b), Episodic rifting and volcanism at Krafla in North Iceland: Radon (222) emission from fumaroles near Leirhnjukur. J. Geophys. Res. 86, B12, 11,806-11,814.

HAUKsson, E. and GodDARD, J. G. (1981), Radon earthquake precursor studies in Iceland. J. Geophys. Res. $86, \mathrm{~B} 8,7037-7054$.

HELGESON, H. C. (1969), Thermodynamics of hydrothermal systems at elevated temperatures and pressures. American Journal of Science 267, 729-804.

HoluB, R. F. (1981), Time dependent radon diffusion in rocks. In The Natural Radiation Environment, Proceedings of the 2nd Special Symposium on the Natural Radiation Environment, January 1981, India (K. G. Vohra, K. C. Pillai, U. C. Mishra, S. Sadasivon, eds.) pp. 391-397.

HoluB, R. F. and BRADY, B. T. (1981), The effect of stress on radon emanation from rock. J. Geophys. Res. $86, \mathrm{~B} 3,1776-1784$.

Honda, M., Kurita, K., Hamano, Y. and Ozima, M. (1982), Experimental studies of He and Ar degassing during rock fracturing. Earth and Planetary Science Letters 59, 429-436.

IMAMURA, G. (1947), Report on the observed variation of the Tochiomata hot spring immediately before the Nagano earthquake of July 15, 1947. (In Japanese), Kagaku 11, 16-17.

IRWIN, W. P. and BARNES, I. (1980), Tectonic relations of carbon dioxide discharges and earthquakes. J. Geophys. Res. 85, B6, 3115-3121.

ISRAELSSON, S. (1980), Meteorological influences on atmospheric radioactivity and its effects on the electrical environment. In The Natural Radiation Environment III. Symposium Proceedings, Houston, Texas, April 23-28, 1978, Rep. CONF-780422, U.S. Dept. of Energy, Washington, D.C., pp. 210-225.

JIANG, F.-L. and LI, G.-R. (1981a), The application of geochemical methods in earthquake prediction in China. Geophys. Res. Lett. 8, 5, 469-472.

JIANG, F.-L. and LI, G.-R, (1981b), Experimental studies of the mechanisms of seismo-geochemical precursors. Geophys. Res. Lett. 8, 5, 473-476.

Katoh, K., Nishizawa, O., Kusunose, K. and IKEDA, K. (1985), An experimental study on variation of radon emanation from westerly granite under uniaxial compression, Part 1: J. Seismological Society of Japan, 173-182.

KAWABE, I. (1985), Anomalous changes of CH4/Ar ratio in subsurface gas bubbles as seismogeochemical precursors at Matsuyama, Japan. PAGEOPH 122, 196-214.

KAWABE, I., MAKI, T. and SUGISAKI, R. (1981), Geochemical study on surface gases in the fault zones of Shikoku Island, Japan--(1): Bubble gas survey around the Median Tectonic Line. Geochem. J. 15, 183-191.

KHARAKA, Y. K. and BARNES, I. (1973), SOLMNEQ: Solution-mineral equilibrium computations. U.S. Geological Survey Computer Contribution, Menlo Park, CA., 81 p.

KING, C.-Y. (1978), Radon emanation on San Andreas Fault. Nature 271, 516-519.

KING, C.-Y. (1980a), Geochemical measurements pertinent to earthquake prediction. J. Geophys. Res. 85, B6, 3051 .

KING, C.-Y. (1980b), Radon emanation in tectonically active areas. In The Natural Radiation Environment III. Symposium Proceedings, Houston, Texas, April 23-28, 1978, Rep. CONF-780422, U.S. Dept. of Energy, Washington, D.C., pp. 175-182.

KING, C.-Y. (1985a), Radon monitoring earthquake prediction in China. Earthquake Prediction Research $3,47-68$.

KING, C.-Y. (1985b), Impulsive radon emanation on a creeping segment of the San Andreas Fault, California. PAGEOPH 122, 340-352.

KING, C.-Y. (1986), Gas geochemistry applied to earthquake prediction: An overview. J. Geophys. Res. 91, B12, 12,269-12,281.

King, C.-Y., Evans, W. C., Presser, T. and Husk, R. H. (1981), Anomalous chemical changes in well waters and possible relation to Earthquakes. Geophys. Res. Lett. 8, 5, 425-428.

KITA, I. and MATSUO, S. (1982), $\mathrm{H}_{2}$ generation by reaction between $\mathrm{H}_{2} \mathrm{O}$ and crushed rock: An experimental study on $\mathrm{H}_{2}$ degassing from the active fault zone. J. Geophys. Res. 87, B13, 10,789-10,795.

Kita, I., Matsuo, S., Wakita, H. and Nakamura, Y. (1980), $\mathrm{D} / \mathrm{H}$ ratios of $\mathrm{H}_{2}$ in soil gases as an indicator of fault movement. Geochem. J. 14, 317-320.

KluSMAN, R. W. (1981), Variations in mercury and radon emission at an aseismic site. Geophys. Res. Lett. $8,5,461-464$.

Klusman, R. W. and Webster, J. D. (1981), Preliminary analysis of meteorological and seasonal influences 
on crustal gas emission relevant to earthquake prediction. Bulletin of the Seismological Society of America $71,1,211-222$.

Kovach, E. M. (1946), Diurnal variations of the radon-content of soil-gas. J. Geophys. Res. 51, 45-55.

Kraner, H. W., SChroeder, G. L. and EVANS, R. D. (1964), Measurements of the effects of atmospheric variables on radon-222 flux and soil-gas concentrations. In The Natural Radiation Environment, Symposium Proceedings, Houston, Texas, Apr. 10-13, 1963, John A. S. Adams and Wayne M. Lowder (eds.), University of Chicago Press, Chicago, 191-214.

KURATA, T. and TSUNOGAI, S. (1986), Exhalation rates of ${ }^{222} \mathrm{Rn}$ and deposition rates of ${ }^{210} \mathrm{~Pb}$ at the earth's surface estimated from ${ }^{226} \mathrm{Ra}$ and ${ }^{210} \mathrm{~Pb}$ profiles in soils. Geochem. Journal 20, 81-90.

Li, G., Jaing, F., WANG, J. and Zhang, P. (1985), Preliminary results of seismogeochemical research in China. PAGEOPH 122, 218-230.

LiU, K.-K., YUI, T.-F., YeH, Y.-H., Tsai, Y.-B. and TenG, T.-L. (1985), Variations of radon content in groundwaters and possible correlation with seismic activities in northern Taiwan. PAGEOPH 122, 231244.

Mavlyanov, G. A., Sultankhodzhayev, A. N., Gorbushina, L. V., Tyminskiy, V. G., Spiridonov, A. I. and KHASANOVA, L. A. (1971), Role of radioisotope indicators of ground water in determining earthquake precursors. Soviet Hydrology: Selected Papers, Issue No. 1, 94-97.

MeGUMI, K. and MAMURO, T. (1973), Radon and thoron exhalation from the ground. J. Geophys. Res. 78, 11, 1804-1808.

MEI, S. (1984), Short-term and immediate precursors to continental earthquakes in China. International Symposium on Continental Seismicity and Earthquake Prediction, Seismological Press, pp. 440-461.

Melvin, J. D., Shapiro, M. H. and Copping, N. A. (1978), An automated radon-thoron monitor for earthquake prediction research. Nuclear Instr. Methods 153, $239-251$.

MochizUKi, S. and SeKikawa, T. (1980), Radon-222 exhalation and its variation in soil air. In The Natural Radiation Environment III, Symposium Proceedings, Houston, Texas, April 23-28, 1978, Rep. CONF780422, U.S. Dept. of Energy, Washington, D.C., pp. 105-113.

MoGi, K. (1977), Dilatancy of rocks under general triaxial stress states with special reference to earthquake precursors. Earthquake Research Institute, Tokyo University, Tokyo, Japan, pp. 203-217.

Mogro-Campero, A., Fleischer, R. L. and LiKeS, R. S. (1980), Changes in subsurface radon concentration associated with earthquakes. J. Geophys. Res. 85, B6, 3053-3057.

Nagata, S., Oba, N., Ikeda, K., Nagal, S., Goto, H. and Abe, K. (1979), Chemical compositions of dissolved gases in groundwaters in the Izu Peninsula and its variation in relation to the 1976 microearthquake swarms and the 1978 Izu-Oshima-Kinkai earthquake. Report of Geological and Geochemical Studies on the Izu-Oshima-Kinkai Earthquake of 1978 (T. Kakimi and N. Tono, eds.) Special Report No. 7, Geological Survey of Japan, pp. 119-128, 1979.

NERSESOV, I. L. (1984), Development of earthquake prediction in the USSR. International Symposium on Continental Seismicity and Earthquake Prediction, Seismological Press, pp. 373-383.

NoGuchI, M. and WAKITA, H. (1977), A method for continuous measurement of radon in groundwater for earthquake prediction. J. Geophys. Res. 83, 1353-1357.

OKABE, S. (1956), Time variation of the atmospheric radon-content near the ground surface with relation to some geophysical phenomena. Memoirs of The College of Science, University of Kyoto, Series A, Vol. XXVIII, No. 2, Article 1, pp. 99-115.

O'NEIL, J. R. and KING, C. -Y. (1981), Variations in stable-isotope ratios of ground waters in seismically active regions of California. Geophys. Res. Lett. 8, 5, 429-432.

PEARSON, J. E. and JoNES, G. E. (1965), Soil concentrations of 'emanating radium-226' and the emanation of radon-222 from soils and plants. Tellus $18,655-661$.

REIMER, G. M. (1980), Use of soil-gas helium concentrations for earthquake prediction: Limitations, imposed by diurnal variation. J. Geophys. Res. 85, B6, 3107-3114.

REIMER, G. M. (1981), Helium soil-gas variations associated with recent central California earthquakes: Precursor or coincidence. Geophys. Res. Lett. 8, 5, 433-435.

Reimer, G. M. (1985), Prediction of central California earthquakes from soil-gas helium fluctuations. PAGEOPH 122, 369-375.

RicE, J. R. and RuDNICKI, J. W. (1979), Earthquake precursory effects due to pore fluid stabilization of a weakening fault zone. J. Geophys. Res. 84, B5, 2177-2193. 
RoBiNson, R. and WHITEHEAD, N. E. (1986), Radon variations in the Wellington region, New Zealand, and their relation to earthquakes. Earthquake Prediction Research 4, 69-82.

RoELOFFs, E. (1987), Hydrologic precursors: A critical review. This volume.

ROELOFFS, E. and BREDEHOEFT, J. D. (1985), Coseismic response of water wells near Parkfield, California, to the August 4, 1985 North Kettleman Hills earthquake. (abstract) Eos, Transactions of the American Geophysical Union 66, 986 .

ROELOFFS, E. and RUDNICKI, J. W. (1985), Coupled deformation-diffusion effects on water level changes due to propagating creep events. PAGEOPH 122, 560-582.

ROELOFFS, E. and RUDNICKI, J. W. (1986), The effect of fault plane impermeability on pore pressure changes induced by propagating creep events. (abstract) Eos, Transactions of the American Geophysical Union $67,272$.

Sano, Y., Nakamura, H., Wakita, H., Notsu, K. and Kobayashi, Y. (1986), ${ }^{3} \mathrm{He} /{ }^{4} \mathrm{He}$ anomalies associated with the 1984 Western Nagano earthquake: Possibly induced by a diapiric magma. J. Geophys. Res. 91 B12, 12,291-12,295.

Santoyo, E., Verma, S. P. and Portugal-Marin, E. (1987), Possible anomalous geochemical precursor of the 19 September Mexican earthquake (Ms $=8.1$ ). Bulletin of Volcanology, in review.

SARDAROv, S. S. (1981), Empirical relationship between anomalies that are short-term predictors of impending earthquakes and earthquake parameters. Doklady Akademiyi Nauk SSSR 258, 4, 837-841.

SATAKe, H., OHASHI, M. and Hayashi, Y. (1985), Discharge of $\mathrm{H}_{2}$ from the Atotsugawa and Ushikubi Faults, Japan, and its relation to earthquakes. PAGEOPH 122, 185-193.

SATo, M. and MCGEE, K. A. (1981), Continuous monitoring of hydrogen on the south flank of Mount St. Helens: U.S. Geological Survey Professional Paper 1250, 209-219.

Sato, M., Sutton, A. J. and McGee, K. A. (1985), Anomalous hydrogen emissions from the San Andreas Fault observed at the Cienega winery, Central California. PAGEOPH 122, 376-391.

Sato, M., Sutton, A. J., MCGeE, K. A. and Russell-Robinson, S. (1986), Monitoring of hydrogen along the San Andreas and Calaveras Faults in central California in 1980-1984 J. Geophys. Res. 91, B12, 12,31512,326 .

SCHERY, S. D., GAEDDERT, D. H. and WilkENING, M. H. (1982), Transport of radon from fractured rock. J. Geophys. Res. 87, B4, 2969-2976.

SCHOLZ, C. H. (1987), Mechanisms of seismic quiescences. This volume.

Scholz, C. H., Sykes, L. R., Aggarwal, Y. P. (1973), Earthquake prediction: A physical basis. Science $181,4102,803-810$.

Shapiro, M. H., Melvin, J. D., Tombrello, T. A., Fong-liang, J., Gui-Ri, L., Mendenhall, M. H., Rice, A., Epstein, S., Jones, V. T., MASDEA, D. and KurTz, M. (1982), Correlated radon and $\mathrm{CO}_{2}$ variations near the San Andreas Fault. Geophys. Res. Lett. 9, 5, 503-506.

Shapiro, M. H., Rice, A., Mendenhall, M. H., Melvin, J. D. and Tombrello, T. A. (1985), Recognition of environmentally caused variations in radon time series. PAGEOPH 122, 309-326.

SHIRATOI, K. (1927), The variation of radon activity of hot springs. Science Reports of the Tohoku Imperial University, Ser. 3, 16, 614-621.

SIBSON, R. H. (1981), Fluid flow accompanying faulting: Field evidence and models: Earthquake Prediction: An International Review. American Geophysical Union, Maurice Ewing Series 4, pp. 593603.

Smith, A. R., Bowman, H. R., Mosier, D. F., Asaro, F., Wollenderg, R. A. and King, C.-Y. (1976), Investigation of radon-222 in subsurface waters as an earthquake predictor. IEEE Transactions of Nuclear Science NS-23, 694-698.

SOBOLEv, G. A. (1984), The study of failure forerunners on the big samples. International Symposium on Continental Seismicity and Earthquake Precursors, Seismological Press, pp. 515-524.

Sobolev, G., Spetzler, H. and Salov, B. (1984), Precursors in rocks while undergoing anelastic deformations. J. Geophys. Res. 83, B4, 1775-1784.

STEELE, S. R. (1981), Radon and hydrologic anomalies on the rough creek fault: Possible precursors to the M 5.1 Eastern Kentucky earthquake, 1980. Geophys. Res. Lett. 8, 5, 465-468.

STEELE, S. R. (1985), Anomalous radon emanation at local and regional distances preceding earthquakes in the New Madrid Seismic Zone and adjacent areas of the Central Mid-Continent of North America, 198184. PAGEOPH 122, 353-368. 
SugISAKI, R. (1978), Changing $\mathrm{He} / \mathrm{Ar}$ and $\mathrm{N}_{2} / \mathrm{Ar}$ ratios of fault air may be earthquake precursors. Nature 275, 209-211.

SUgISAKI, R. (1980), Deep-seated gas emission induced by the earth tide: A basic observation for geochemical earthquake prediction. Science 212, 1264-1266.

SUGISAKI, R. (1985), Relation between hydrogen emission and seismic activities. PAGEOPH 122, 175-184.

SugISAKI, R., ANNO, H., ADACHI, M. and HIROTAKA, U. (1980), Geochemical features of gases and rocks along active faults. Geochem. Journal 14, 101-112.

Sugisaki, R., Ido, M., Takeda, H., Isobe, Y., Hayashi, Y., Nakamura, N., Satake, H. and Mizutani, Y. (1983), Origin of hydrogen and carbon dioxide in fault gases and its relation to fault activity. The Journal of Geology 91, 3, 239-258.

SUGISAKI, R. and SUGIURA, T. (1986), Gas anomalies at three mineral springs and a fumarole before an inland earthquake, central Japan. J. Geophys. Res. 91, B12, 12,296-12,304.

TALWANI, P. (1981), Earthquake prediction studies in South Carolina: In Earthquake Prediction: An International Review. American Geophysical Union, Maurice Ewing Series 4, pp. 381-393.

TALWANI, P., MOORE, W. S. and ChIANG, J. (1980), Radon anomalies and microearthquakes at Lake Jocassee, South Carolina. J. Geophys. Res. 85, B6, 3079-3088.

TANNER, A. B. (1964), Radon migration in the ground: A review. In The Natural Radiation Environment, Symposium Proceedings, Houston, Tex., Apr. 10-13, 1963, John A. S. Adams and Wayne M. Lowder (eds.), pp. 161-190, University of Chicago Press, Chicago.

TANNER, A. (1980), Radon migration in the ground: $A$ supplementary review. In Natural Radiation Environment III (T. F. Gesell and W. M. Lowder, eds.), Symposium Proceedings, Houston, Texas, April 23-28, 1978, Rep. CONF-780422, U.S. Dept. of Energy, Washington, D.C., 1, pp. 5-56.

TENG, T. L. (1980), Some recent studies on ground water radon content as an earthquake precursor. J. Geophys. Res. 85, B6, 3089-3099.

TENG, T. L. (1984), Some developments on earthquake precursor monitoring in southern California. International Symposium on Seismology and Earthquake Prediction, Seismological Press, pp. 462479.

Teng, T. L. and Henyey, T. L. (1984), The detection of nanoearthquakes. In Earthquake Prediction: An International Review, American Geophysical Union, Maurice Ewing Series 4, pp. 533-542.

Teng, T. L., SUN, L. F. and MCRANeY, J. K. (1981), Correlation of ground water radon anomalies with earthquakes in the greater Palmdale bulge area. Geophys. Res. Lett. 8, 5, 441-444.

Thomas, D. M., CuFF, K. E. and Cox, M. E. (1986), The association between ground gas radon variations and geologic activity in Hawaii. J. Geophys. Res. 91, B12, 12,186-12,198.

Thomas, D. M. and KoYANAGI, R. Y. (1986), The association between ground gas radon concentrations and seismic and volcanic activity at Kilauea volcano. Eos, Transactions of the American Geophysical Union (abstracts) 67, 44, 905.

Tombrello, T. A., Shapiro, M. H., Melvin, J. D., Mendenhall, M. H. and Rice, A. (1984), Remote monitoring of seismo-geochemical variables in southern California. International Symposium on Continental Seismicity and Earthquake Prediction, Seismological Press, pp. 541-547.

UlOMOV, V. I. and MAVASHEV, B. Z. (1971), Forerunners of the Tashkent earthquake. Izvestia Akadamiyi Nauk Uzbeckistan SSR, pp. 188-200.

Varshal, G. M., Sobolev, G. A., Barsukov, V. L., Koltsov, A. V., Kostin, B. I., Kudinova, T. F., StakheYev, Y. I. and TRETYAKova, S. P. (1985), Separation of volatile components from rocks under mechanical loading as the source of hydrogeochemical anomalies preceding earthquakes (Results of a large-scale model experiment). PAGEOPH 122, 463-477.

WAKITA, H. (1977), Geochemistry as a tool for earthquake prediction. U.S.-Japanese Seminar on Earthquake Precursors, Tokyo, Japan, pp. 175-183.

WAKITA, H. (1978), 'Helium Spots': Caused by a diapiric magma from the upper mantle. Science 200, 430 431.

WAKITA, H. (1981), Precursory changes in ground water prior to the 1978 Izu-Oshima-Kinkai Earthquake. In Earthquake Prediction: An International Review, American Geophysical Union, Maurice Ewing Series 4, pp. 527-532.

WAKITA, H. (1982), Changes in groundwater level and chemical composition. In Earthquake Prediction Techniques. Chapter 8, (T. Asada, ed.) (University of Tokyo Press) pp. 175-216. 
WAKITA, H. (1984), Groundwater observations for earthquake prediction in Japan. International Symposium on Continental Seismicity and Earthquake Prediction, Seismological Press, pp. 494-500.

Wakita, H., Nakamura, Y., Notsu, K., NoGuchi, M. and Asada, T. (1980a) Radon anomaly: A possible precursor of the 1978 Izu-Oshima-kinkai earthquake. Science 207, 882-883.

Wakita, H., Nakamura, Y., Kita, I., Fujil, N. and Notsu, K. (1980b), Hydrogen release: New indicator of fault activity. Science 210, 188-190.

WAKITA, H., NAKAMURA, Y. and SANO, Y. (1985), Groundwater radon variations reflecting changes in regional stress fields. Earthquake Prediction Research 3, 545-557.

WANG, C.-Y. and MORRISON, H. F. (1975), Electrical resistivity of granite in frictional sliding: Application to earthquake prediction. Geophys. Res. Lett. 2, 12, 525-528.

Wang, C.-Y., Sundaram, P. N. and Goodman, R. E. (1978), Electrical resistivity changes in rocks during frictional sliding and fracture. PAGEOPH 116, 717-731.

WANG, C., WANG, Y. and GuO, Y. (1984), Some results of groundwater level observation in earthquake areas in China during the past 15 years. International Symposium on Continental Seismicity and Earthquake Prediction, Seismological Press, pp. 501-513.

WARE, R. H., ROECKEN, C. and WySs, M. (1985), The detection and interpretation of hydrogen in fault gases. PAGEOPH 122, 392-402.

WoODCOCK, A. H. (1987), Mountain breathing revisited-the hyperventilation of a volcano cinder cone. Bulletin of the American Meteorological Society 68, 2, 125-130.

WoOdCock, A. H. and Friedman, I. (1979), Mountain breathing-Preliminary studies of air-land interaction on Mauna Kea, Hawaii. U.S. Geological Survey Professional Paper 1153A.

Wyss, M. (1985), Precursors to large earthquakes. Earthquake Prediction Research 3, 519-543.

YAMAUCHI, T. and SHIMO, M. (1982), Radon concentration in galleries and its relation to the earthquake occurrence. J. of the Seismological Society of Japan 35, 3, 435-446.

ZHANG, G. and FU, Z. (1981), Some features of medium-and short-term anomalies before great earthquakes. In Earthquake Prediction: An International Review, American Geophysical Union, Maurice Ewing Series 4, pp. 497-509.

ZHU, F., QUAN, Y., GU, H., XU, X., GuAN, X. (1984), Re-examination of the anomalous phenomena taken as precursors before the Haicheng earthquake of 1975. International Symposium on Continental Seismicity and Earthquake Prediction, Seismological Press, pp. 571-581.

ZIA, R. (1984), Forewarning phenomena for the earthquake that took place in the Basilicata and Campania regions of South Italy on November 23rd 1980. International Symposium on Continental Seismicity and Earthquake Prediction, Seismological Press, pp. 534-540.

ZOBACK, M. D. and BYERLEE, J. D. (1975a), The effect of microcrack dilatancy on the permeability of westerly granite. J. Geophys. Res. 80, 5, 752-755.

ZOBACK, M. D. and BYERLEE, J. D. (1975b), The effect of cyclic differential stress on dilatancy in westerly granite under uniaxial and triaxial conditions. J. Geophys. Res. 80, 11, 1526-1530.

(Received 26th January, 1987, revised/accepted 5th August, 1987) 